\title{
Egypt's Popular Uprising and the Stakes of Medical Neutrality
}

\author{
Sherine F. Hamdy ${ }^{1} \cdot$ Soha Bayoumi
}

(C) Springer Science+Business Media New York 2015

\begin{abstract}
Amidst the recent political uprisings in the Arab region, physicians and other healthcare workers have found themselves in the crossfire. This paper focuses on Egypt's doctors, paying special attention to how many have both appealed to and practiced medical neutrality as its own potent and contested political stance, particularly since the period of military rule following Mubarak's removal from power. Our paper draws on interviews with physicians who served as volunteers in the field hospitals in the days of unrest and violence, and with others who played a major role in documenting protesters' injuries, police brutality, and other forms of state violence against unarmed citizens. Based on interviews with doctors who belong to organizations such as "Tahrir Doctors" and "Doctors Without Rights," our paper reveals how these doctors' commitment to professional ethics put them at odds with the orders of military personnel, rendering their appeal to "medical neutrality" a weighty political act in and of itself.
\end{abstract}

Keywords Medical neutrality · Medical ethics - Doctors - Arab Spring · Egypt $\cdot$ Political conflict

\section{Introduction}

Amidst the political uprisings in the Arab region that began in 2011, physicians and other healthcare workers found themselves in the crossfire. This article focuses on Egyptian physicians who risked their lives to attend to the wounded, withstood

Sherine F. Hamdy

sherine_hamdy@brown.edu

1 Department of Anthropology, Brown University, Providence, RI, USA

2 Department of the History of Science, Harvard University, Cambridge, MA, USA 
political pressures to deny state violence, and set up and staffed field hospitals in the middle of Egypt's cities at points of violent conflict. For some of these young medics, their delivery of first aid and emergency medical care in the streets formed a sort of political awakening from an apathetic and single-minded focus on getting through their medical training. For others, particularly those of an older generation, the uprisings were the culmination of their decades-long commitment to fighting for health and social justice, despite social and political fragmentation within their profession. The article focuses on theses physicians' appeal to and practice of medical neutrality. It aims to problematize and contextualize the concept of medical neutrality as deployed by these medics and perceived by other actors surrounding them, particularly the police and the military, during the violent confrontations that marked the period following Mubarak's ouster and the rule of the military council.

\section{Medical Neutrality Between Immunity and Impartiality}

Medical neutrality is often understood in international law and politics as referring to the jus in bello principle of noninterference with medical services in times of armed conflict. In its formal conception, the most flagrant violations of medical neutrality include attacks on hospitals, patients, medical personnel, and medical transportation. The Geneva Conventions, which resulted in the creation of the International Committee of the Red Cross in 1949, are considered the most prominent articulation of this principle. A second aspect of medical neutrality is the obligation for medical personnel to treat all patients without discrimination. Despite the fact that immunity and impartiality are quite distinct concepts, they are often deployed jointly in the same phrase "medical neutrality." The World Medical Association, for example, a confederation of national medical associations, affirms the obligation of " $[\mathrm{g}]$ overnments, armed forces and others in positions of power [to] comply with the Geneva Conventions to ensure that physicians and other healthcare professionals can provide care to everyone in need in situations of armed conflict and other situations of violence" including a "requirement to protect healthcare personnel and facilities." This appeal to immunity is preceded with an affirmation of physicians' duty to impartiality in the statement: "[t]he medical duty to treat people with humanity and respect applies to all patients. The physician must always give the necessary care impartially and without discrimination on the basis of age, disease or disability, creed, ethnic origin, gender, nationality, political affiliation, race, sexual orientation, or social standing or any other similar criterion" (emphasis added) (World Medical Association). ${ }^{1}$

In its examination of medical neutrality, this article incorporates the two elements constitutive of the concept, both because they are analytically significant and because the medical personnel in Egypt who inform this study often invoke the dual meanings of this term. By examining the narratives of physicians who grapple with their dual roles as political actors and impartial medical practitioners deserving

\footnotetext{
${ }^{1}$ For a detailed discussion of the principle of medical neutrality as both immunity and impartiality, see Michael Gross (2006).
} 
of immunity, we highlight the tensions that inhere in the concept of medical neutrality. In unpacking these questions, we aim to move calls for "medical neutrality" from a Manichean moralism that merely condemns its violations. We aim instead to interrogate the social conditions necessary for healthcare workers and clinics to be spared from political violence, and to be able to attend to patients indiscriminately.

\section{The Problematic of Neutrality: Who Is Neutral?}

The very notion of "neutrality" or "impartiality" tends to raise red flags for critical medical anthropologists and other social scientists, for it often serves to conceal unequal power relations. Those who speak in the name of impartiality are often in positions of power and wield the term "impartiality" to make their privilege appear inevitable and natural. In this sense, the very concept of neutrality "carries a hopeless burden of critique" (Redfield 2011:53).

Yet what interests us in this article is how physicians claimed impartiality as a strategy against the unchecked abuses of state power. ${ }^{2}$ We highlight how the very act and commitment to impartiality can function as a potent and radical challenge to the military regime's stance that it is the only and ultimate sovereign authority to determine who can live and who can die. The physicians who stood by and tended to the protesters challenged state authority in this very act, particularly those who erected and staffed field hospitals and those who documented state violence in direct refutation of state propaganda. To justify their actions-attending to wounded protesters who were attacked by riot police - these physicians evoked the idea of medical impartiality as a professional ethos-one blatantly disregarded by the state institutions deployed to crush the protests. The doctors soon found themselves as targets of state violence during the period of military rule following Mubarak's removal from power.

We will examine three different ways in which doctors' participation in the popular uprisings challenge the dominant understanding of "medical neutrality." First, we extend Peter Redfield's insight that the very concept of "medical neutrality" is an artifact of interstate war that must be rethought for today's intrastate political violence (Redfield 2013). Second, we demonstrate that practicing medicine impartially is not inherently constitutive of doctors' practice; rather it must be actively cultivated and can only be practiced and sustained under particular conditions. Third, although paradoxically, the physicians' "neutrality" gives them the veneer of being outside of politics, yet the practice of medical neutrality in fact requires a political stance that directly challenges the status quo of state violence and radical social inequality (Redfield 2013, Birn and Brown 2013).

\footnotetext{
${ }^{2}$ In this sense, like Redfield, we are interested in how medical neutrality can be "as much a strategic weapon of the weak as a hegemonic assumption of the powerful" (2013:118).
} 


\section{Medical Neutrality as a Legacy of War}

Contemporary activists who prioritize the call for states to adhere to medical neutrality, most notably the U.S. based organization Physicians for Human Rights (PHR), argue that "attacks [on healthcare professionals, facilities, and patients] are not a natural part of conflict, but are deliberate violations of the principle of Medical Neutrality" (Physicians for Human Rights). Yet as Peter Redfield demonstrates in his ethnography of the international humanitarian organization Médecins Sans Frontières (MSF, or Doctors Without Borders) international conventions of "medical neutrality" are part of the law of war and an outcome of agreements by European countries since the nineteenth century to help civilize war not to eradicate it. (Redfield 2013). ${ }^{3}$ In this context, medical neutrality is expected or required in a situation of symmetric, interstate warfare where conventional armies are deployed against each other and rely on a principle of reciprocity and a form of quid pro quo ethics. For today's humanitarians, "medical neutrality" as understood in the historical context in which it emerged is out of sync for two reasons: (1) it originated as an instrument of war, whereas humanitarians generally position themselves as outside and against all forms of war and (2) it carries with it the assumptions that "war" is always or only the outcome of interstate military violence, whereas humanitarians repeatedly find themselves in large-scale intrastate humanitarian disasters, such as that in Biafra, Rwanda, Israel/Palestine, and Syria (Redfield 2011, 2013).

Yet if the principle of medical neutrality is in some ways out of sync with today's realities, it nonetheless circulates as a valuable currency in journalism and the practice of human rights activism. In the early days of the 2011 popular uprisings in Egypt, local human rights workers documented state violence against protestors, including violations of medical neutrality, as understood and defined by organizations such as the International Committee of the Red Cross and Physicians for Human Rights. Human rights staff documented incidences of ambulances delivering protesters to the police rather than to emergency rooms, of ambulances being used to transport weapons into the square to be used against the protesters, and of physicians in state hospitals refusing to treat the injured or handing them over to the police. ${ }^{4}$ There were tremendous pressures on doctors by riot police, hospital administrators, or state security for them to nullify or falsify evidence of state violence. Not all physicians were able to withstand or confront these pressures. For example, in an article written by Dr. Mohamed El-Fiki, an Alexandria-based neurosurgeon, he reports that hospital authorities banned younger physicians from listing gunshot wounds as cause of death on death certificates of those who died at Alexandria University Hospital in the first few days of protests when the Central Security police forces were shooting demonstrators in Alexandria (El-Fiki and Rousseau, 2011:31). El-Fiki writes

\footnotetext{
${ }^{3}$ Prior to this time, notions of partial or imperfect neutrality were recognized. As the scope of war widened in the nineteenth century, the concepts of "neutrality" and "conflict" took on more absolute, fixed meanings (Redfield 2011).

${ }^{4}$ Unpublished reports and collected testimonies by The Egyptian Initiative for Personal Rights.
} 
...[D]eath certificates were collectively reported by medical members of the hospital administration as 'acute failure of circulation and breathing.' This complicity with the state, even by hospital employees, reflects how much the dictatorial regime had infiltrated every aspect of people's lives and how false its data had become. (El-Fiki and Rousseau 2011:31)

El-Fiki's use of the word "even" reflects a view that doctors should have been more resistant to such political pressures and maneuverings and how poor the state of affairs had become for "even" the doctors to be tarnished. The doctor, in this view, should be a reliable witness, and indeed, many international human rights organizations, such as Amnesty International, interview doctors for an indication or temperature reading of the scale and quality of mass violence in times of political conflict. For example, doctors may report a number of casualties and what kind of injuries they saw: bullet wounds, crush injuries, or burns (Gulland 2011). ${ }^{5}$

But in this paper, we ask rather than assume: under what circumstances and conditions is a physician a reliable witness or evaluator of human suffering? As the documentation of physicians' complicity in the state violence attests, many physicians were willing to side with the regime. As in many national contexts, physicians were regarded as investments of resources upon which to be ultimately capitalized; they were trained medically at the expense of the state, and their duties were to serve the interests of national health. Since the building of the first medical school in the 1820 s by the Ottoman viceroy Mehmet Ali, doctors were used to help ensure a vigorous army and a population from which to recruit military power (Fahmy 1997). Following the 1952 coup, the Egyptian medical profession mostly coalesced around the Nasserist project, which allowed Egyptian doctors to assume control of the health by nationalizing expatriate hospitals and restricting the practice of foreign doctors. The mutual agreement between doctors and the State-in which doctors align with political projects and receive professional benefits-continued in different forms under successive regimes (Shukrallah and Khalil 2012).

Today, upon graduation and appointment to public hospitals, physicians tend to patients who seek treatment free of charge or for nominal fees, and the number of patients to which the physicians tend is neither reflected in nor incentivized by their salaries. Physicians often work in a public hospital for a low government salary but supplement their work with private practice in order to make ends meet. Upon entering medical school, physicians enter into a system of exchange with the State which binds each to the other in cycles of indebtedness and reciprocity: they receive education, training, a permanent job and social prestige in exchange for their subsequent work in public clinics and, in some cases, service in military hospitals. The treatment of poor patients in public hospitals is largely dependent upon the physician's own moral scruples and ability to successfully triage with limited resources. The fact that the discretion of the physician plays a large role in patients' treatment outcomes has much to do with why the perception of the physician's role

\footnotetext{
5 The focus on doctors and health in times of conflict is part of a global trend of codifying international humanitarianism through moral and legal categories. As Redfield puts it, "The fiction of standing outside battle (hors de combat) could now [since the nineteenth century] be predetermined by professional status as a medical worker and bodily states related to suffering" (Redfield 2011:59).
} 
has been so dramatically polarized between the cultural ideal of a morally superior "doctor of confidence" and the vilified role of a "butcher or medicine-monger" (Hamdy 2012).

As in other authoritarian contexts, doctors are periodically recruited to aid in suppressing political dissidents, as in the use of torture or in the protection of ousted leaders from serving trial on medical grounds. Over the last years of Mubarak's rule, it was widely known throughout Egypt that the Ministry of Interior under Habib ElAdly grew more and more emboldened in its torturing and extermination of political dissidents. One of the many rallying cries that spurred indignation and rage on the part of protestors was the case of Khaled Sa'id, a young Alexandrian who was beaten to death in June 2010 in front of an internet café near his home. It was not only the impunity of police brutality but also the complicity of medical authorities that had provoked outrage over the years. Most notably, in the case of Sa'id, the forensic examiners' autopsy report concurred with the police statement, both of which denied the violence done to his body and made spurious allegations that his death was drug related.

With the exception of physicians who were political activists or members of dissident parties, doctors were largely exempt from the daily police harassment that plagued other sectors of society. The large-scale police violence unleashed on the streets of Cairo in January 2011 was unprecedented in their lifetimes. Many of the physicians joined the protests because they themselves believed in the protest movement and had their own political grievances. Many carried first-aid supplies with them in case they were needed. Later, when the riot police's violence became expected, many physicians joined the streets in their capacity as healthcare workers, wishing to stem the flow of injured and maimed protestors who had been pouring into emergency rooms. Initially, doctors identifiable by their white coats, or by other more general markers of middle-class prestige, were largely spared the brunt of the violence.

This changed in November 2011, nine months after Mubarak's removal from power, when riot police attacks on protesters resumed. In the alleys near Tahrir Square, the clashes that came to be known as "The Battle of Mohamed Mahmoud Street" included police raids and attacks on the makeshift hospitals. As in the preceding unrest in January, physicians again became witnesses to state violence against unarmed protesters, negating the official statements. But in the November 2011 clashes something unprecedented happened as well: physicians themselves became the explicit targets of state violence. Field hospitals in Tahrir were targeted with teargas canisters, doctors were shot at and beaten by the police, and several other doctors were arrested. ${ }^{6}$ As young physician after physician related his or her story of military assault-many of them in bandages or recovering from bruisessimilar themes emerged: "And I was wearing my white coat clearly." "And I showed my official ID [in which it is recorded that I am a physician]." "And I was obviously tending to the injured." They insisted, seemingly in disbelief, that the

\footnotetext{
6 The Egyptian Initiative for Personal Rights, "Field Doctors Bear Witness to the Targeting of Field Hospitals in Tahrir Square by Security Forces and Military" http://eipr.org/node/1314 [Last accessed February 27, 2015].
} 
soldiers had knowingly shot at, beaten and thrown rocks and tear gas canisters at them, as doctors. ${ }^{7}$

In a December 2011 press conference, Dr. Mona Mina, coordinator of the group "Doctors without Rights" and one of the prominent doctors in the Tahrir field hospitals, alerted the assembled audience of reporters that the very ethical foundation of medical professionalism was under attack. She insisted that a fundamental tenet of the medical profession is the principle of medical neutrality by which two separate meanings are evoked: (1) the impartiality of the physician, whose charge is to treat whoever is in need of treatment, regardless of ethnicity, religion, race, or political affiliation and (2) the convention of medical immunity in which warring parties agree that medical personnel and patients should be spared attack. Several of the young physicians who spoke at the podium emphasized their commitment to medical neutrality in both senses. For example, one young physician related the following story, "I told the soldiers who kicked and beat me: 'I am a doctor! As a doctor it is my job to treat whoever is in need. If you, who is beating me, ever need medical attention, it is my duty to treat you!'” The physician sought to explain to the officer why he should be spared from the beating, and in so doing connected the principle of immunity with that of the physician's practice of impartiality. What he was saying was "it is my duty to treat anyone in need, and your duty to protect me so that I can." But this appeal was met with defiance, as the officer balked at the notion that there should be any authority or allegiance higher than that of the military. According to the doctor testifying, "The officer responded with a slew of humiliating insults upon me and my family and shouted, 'It is $I$ who orders you who to treat, you son of a dog!'”

Aya Kamal, a 27-year-old doctor, made the news headlines in May 2012 when she was brutally attacked, arrested, and abused by the military while tending to the injured in a field hospital in Abbasiyya, a Cairo square not far from the Ministry of Defense where a group of revolutionaries had staged a sit-in that was dispersed days later. "[The military] have no respect neither for the doctors nor for the injured," she told us in an interview, a year after her arrest and two-day imprisonment. "They burned a field hospital, stole medications, attacked places of prayer... There are international conventions protecting these spaces... [They] arrested me from a place of prayer [used as a field hospital]. [They] beat me on the stairs of a place of prayer; [they] violated my rights. I still can't believe that I witnessed these images in Egypt. I see these images in the West Bank or in a country stricken by civil war, but not in my own country and at the hands of my own army" (emphasis added).

In invoking the principle of medical neutrality, the doctors argued that in holding up their part of impartiality, it was the duty of the military to uphold their role in ensuring immunity to medical parties and their patients. Yet in erecting a "field hospital" in the midst of a city that was not officially at war, it is unclear on what bases exactly the physicians had expected immunity to be extended to them. While the physicians at the Medics' Press conference of December 2011 spoke of their dismay at the military's egregious violations of the medical facility and of physicians' rights, there is no good reason to suggest that the military would uphold

\footnotetext{
${ }^{7}$ Press conference by doctors in the Press Syndicate, Cairo, Egypt, December 2011.
} 
the idea of medical neutrality in the context of its ongoing large-scale violation of citizens' rights. When the Ministry unleashed its riot police's full brutality onto an unarmed crowd of protestors in January 2011, the State was clearly violating its own constitutional obligations to protect its citizenry. On what basis, then, could physicians feel the State would uphold its international legal obligations (i.e., the signing of the Geneva conventions) to respect medical impartiality and immunity? Was the targeting of physicians any more or less a violation of human rights than attacks on civilians, and in this case, the State's own citizens? Why would an attack on doctors or clinics be any less "natural" than what was already occurring? In other words, if the State's riot police could open fire on families assembling peacefully in their own city, what would stop them from doing the same to citizens wearing white coats? The fact that doctors were largely spared the violence and wrath of riot police and military officers before the events of Mohamed Mahmoud Street in November 2011 is better explained by the elitism of the police-military State than by any prior respect for medical neutrality.

As more humanitarian agencies have focused on healthcare and embraced the notion of "medical neutrality," the role of the doctor in humanitarian conflict has taken on a moral resonance, leaving unquestioned the conditions under which physicians can enact medical impartiality. If indeed physicians were a special moral class, then the popular notions that doctors would inherently treat any wounded person in front of them, regardless of political affiliation, class, race, or gender, might be more plausible. Yet social science research has long discredited claims of moral superiority among groups simply by virtue of their profession, education, or class.

Remembering that medical neutrality was codified as an institution of war-to which state actors agreed in the interests of having their own injured treated-helps us understand why it would not be recognized or respected in situations of intrastate conflict. In repressive political regimes like the one in Egypt, professionals, including doctors, are conditioned to toe the government line. Those who do not soon find themselves on the other end of the State's regime of violence and control-a State with little incentive or interest in upholding a commitment to granting medical immunity. The case of Egypt's popular uprisings demonstrates the particular challenges posed by intrastate violence that have yet to be addressed by international humanitarianism.

When Egypt's popular uprisings erupted in violence, Egyptian human rights workers had difficulty engaging international humanitarian agencies concerned with medical neutrality. ${ }^{8}$ In documenting attacks on the field hospitals, Dalia Abd ElHameed, Gender and Women's Rights Program Officer at the Egyptian Initiative for Personal Rights (EIPR) commented that "the targeting of medical personnel during times of unrest hinders their efforts in providing impartial medical services. Not only that, but it is also a clear violation of the principle of medical neutrality which stipulates that doctors must be protected in times of armed conflict and unrest. This

\footnotetext{
${ }^{8}$ Interview with Amani Massoud and Dalia Abd El-Hameed of The Egyptian Initiative for Personal Rights, conducted by the authors in June 2014.
} 
includes not pursuing either doctors or patients into the place where medical treatment is provided." 9

The Egyptian State's violation of international norms regarding medical neutrality served to bolster the complaints that the human rights organizations were making more generally about the violation of Egyptian citizens' basic rights. They were also quick to realize that medical personnel were not only vulnerable to attacks by State police and security forces; those physicians who treated injured police officers were also subject to physical and verbal harassment from the protestors. As Abd el-Hameed added, "The [...] violations involved in the targeting of doctors become increasingly clear when we realize that they faced verbal abuse from some of the demonstrators during their protection and treatment of wounded police, in accordance with the ethics of their profession. This makes the attacks and the pursuit of [doctors] by the police and the army disgraceful by any standards." While emphasizing the ethical responsibility of medical personnel to treat patients with complete impartiality, "regardless of their political position or any other factor," the human rights advocates at the EIPR also affirmed that this commitment must be matched by a commitment from the state, and the society at large, "to protect the independence and safety of doctors under any circumstances." 10

Yet their difficulties engaging other international humanitarian organizations on this issue demonstrates the multiple challenges of Egyptian human rights advocates. Faced with a State that is all too willing to violate the basic humanity of its citizens, they turn to the international humanitarian community to draw on principles that circulate there, such as that of "medical neutrality." Yet this principle is ostensibly protected within the context of interstate war. If international humanitarian organizations accuse their host State of violating the rights of its own citizens too loudly, they lose their ability to work there and potentially provide needed relief. This double bind is all too familiar to international humanitarian workers who constantly try to strike a balance between the fulfillment of their humanitarian mission and the interests of their host countries (Fassin 2012).

\section{Witnessing Violence and Doctors" "Natural” Response}

Since the early days of the occupation of Tahrir Square by protestors, beginning on January 25, 2011, physicians were immediately confronted with maimed and injured bodies, whether working in the field hospitals delivering first aid or in hospitals adjacent to the square, such as Qasr El-Aini, the largest and oldest public teaching hospital in Cairo. When the violence escalated on January 28, doctors' immediate experience with poisoned, torn, maimed, and bullet-ridden bodies flew in the face of official statements that the military and riot police had only used "crowd control" techniques. Their face-to-face encounters with protestors and activists who appeared sincere in their calls for freedom and dignity exposed the government's

\footnotetext{
9 The Egyptian Initiative for Personal Rights, "Field Doctors Bear Witness to the Targeting of Field Hospitals in Tahrir Square by Security Forces and Military" http://eipr.org/node/1314 [Last accessed February 27, 2015].

10 Ibid.
} 
campaign to discredit them all as druggies, spies, or thugs paid off by foreigners wishing to stir trouble in Egypt.

Three days into the protests, on January 28, 2011, as is now widely known, there was an almost complete shutdown of communications-of the internet and cellular phone services-by the Mubarak regime in an effort to clamp down on the growing protests in Tahrir Square and other epicenters of unrest. Landline services, which were consequently overloaded, were thus compromised. January 28 was also the day of the highest volume of mass casualties, as the regime escalated its attack on protestors with firearms, rubber bullets, tear gas, motor vehicles, and the hurling of blunt heavy objects such as rocks and stones, as well as the use of clubs. Shutting down the communications hampered the ability of the main hospitals, such as Cairo University's Qasr El-Aini Hospital, to mobilize more doctors (Sarhan et al. 2012). As the capacity hospital nearest to Tahrir Square, Qasr El Aini Hospital saw the highest number of protest-related injuries on January 28, and there were nineteen surgeons total from across the different specialties who happened to be on duty that day (Sarhan et al. 2012). Another twenty-two surgeons who were participating in the demonstrations raced to the hospital when the escalation of violence was apparent and when it became clear that the injuries were too extensive for the capacities of the square's field hospital. The hospital's administrative team managed to successfully obtain adequate blood donations from families and friends of the injured. In an article published in the Annals of Surgery, the authors note that 3012 patients were transferred from the Tahrir Square field hospital to the Qasr El-Aini hospital between January 28 and February 4, 2011, where they were triaged (Sarhan et al. 2012). During the first ten hours of the casualties' arrival to the hospital, there was a clear progressive escalation of violence from the riot police: in the first two hours, the patients were suffering respiratory disease due to tear gas inhalation; in the next two hours, injured protestors arrived with shotgun pellets sprayed to the extremities, chest, and face, followed by another wave arriving with nonfatal gunshot wounds. In the final four hours, injured protestors arrived bearing potentially fatal gunshot wounds, aimed more precisely at the head, neck, and chest, indicating the use of snipers. The majority of injuries (93\%) were due to firearms and those aimed at the head and neck indicated intention to kill. ${ }^{11}$ These findings were clear evidence against the official narrative of crowd control or even national "self defense" against the allegedly foreign-funded protestors.

Many of Egypt's physicians played an unexpected role in witnessing violence. For some, like Dr. Taha El-Sebaie, it was this witnessing that hardened their views of the military's actions. Dr. Taha indicated to us, in interviews, that while he was glad to see Mubarak go, by the time of the demonstrations and the sit-in protests on Mohamed Mahmoud Street in November 2011, he, like many Egyptians, felt fed up by the protestors. Why could not they just go home and let the country move along?

\footnotetext{
11 Several non-governmental organizations, particularly the organization Tahrir Doctors, have kept reports of the numbers of injured and the types of injuries for those treated, or at least given first-aid care, in the field hospitals. The Department of Forensics and Toxicology at Cairo University's Medical School and Teaching Hospital, Qasr El-Aini, keeps similar records for those admitted to the Teaching Hospital. Members of these organizations have confirmed these records during our interviews with them in December 2012, June 2013, and June 2014.
} 
Why did they continue to hold everything up? Did not they realize that all their demands could not be met overnight? The feeling that the country was on the brink either of recovery or of disaster had made most Egyptians unsympathetic to the demonstrators. This lack of sympathy was wrought by weariness from the lack of security and police on the streets and the higher rates of crime and economic uncertainty following the onset of the uprisings. It was easier to believe the heroic tale of the army "obeying" the orders of the people after 18 days of glorious occupation, of the noble and peace-loving protestors of Tahrir Square reigning victorious over the brutal regime. The military's bloody repression of protestors in the months following had threatened that narrative. Many, like Dr. Taha, chose either to ignore the military's transgressions or to lay blame on the protestors themselves. Yet in November 2011, after receiving text messages that the number of injured at Mohamed Mahmoud Street was escalating and that the field hospitals were in dire need of medical supplies, Dr. Taha felt, out of a humanitarian impulse, that the least he could do was to rush to the field hospital to donate medical supplies. It was only then and there, seeing the sadistic brutality of soldiers severely beating young unarmed demonstrators, shooting at their eyes, heads, and necks, that Dr. Taha's sympathies shifted. For the next several days, he volunteered at the field hospital, delivering first aid and tending to injured protesters. He returned home, hardened by what he had seen, ready to dispute claims that the protestors were "stalling the country," words he himself had used only days earlier.

Dr. Taha's narrative, as well as those of the Qasr El-Aini Forensics and Ophthalmology departments, ${ }^{12}$ implies, much like the MSF narrative of témoignage, that the simple act of witnessing can both serve as a source of knowledge and forge one's alliances and guide one's moral compass (Redfield 2013). Yet this is not always the case. There are countless other stories of physicians who not only witnessed violence and remained unmoved or unsympathetic toward its victims but also those who themselves participated in or helped deny its occurrence: for example, the physician who carried out the military order to perform so-called "virginity tests" on female protestors (Amnesty International 2012) and the physicians who allegedly tortured and deliberately operated on patients without anesthesia as punishment for their participation in the protests (The Guardian 2013).

The very fact that some physicians (however small or large their percentage) are susceptible to data falsification in their assessment of bloodied and mutilated bodies indicates that physicians' privileged access to corporal suffering does not in and of itself formulate or inform their political persuasions. Thus, while many physicians narrated that their witnessing of state brutality and patient victimhood had shaped their political stances, we take this not as our own cause-effect analysis but rather more as a speech act that performs particular functions for the physicians. First, the idea that injured or mutilated bodies themselves act on the conscience of the doctor, compelling her to political and moral outrage, serves to justify their presence as physicians-protestors active on the scene. In this way, such physicians can counter the dominant narrative that they should stay in their clinics and focus on medicine rather than politics. Second, in narrating their newfound political outrage, by

\footnotetext{
12 Based on interviews with Sherine Hamdy in December 2012 and with Soha Bayoumi in June 2013.
} 
focusing on their face-to-face encounter with injured protestors mobilizing them to act, this particular speech act functions to absolve their earlier apathy and obliviousness to the political repression of which some of them were a part.

How doctors responded to the violence in fact varied tremendously: some physicians ignored it, others abetted, and still others challenged it, much like how Egyptians in wider society positioned themselves along a political spectrum. The physicians' appeal to medical neutrality as a "natural" response to witnessing suffering was, in fact, a potent way to justify and legitimate actions that the State's riot police read as treacherous. Thus, even though the notion of "neutrality" seems to evoke an idea of a position outside or in between the warring sides, there was simply no such place during the uprisings and police response. Medical volunteers at the field hospitals were undoubtedly on the side of the protesters, as were their very acts of documenting and witnessing. They appealed, however, to an ethos that represents what Dr. Mohamed Fattouh of Tahrir Doctors calls "the ideal world that we believed in, despite the complete absence of a justice system." Despite their political loyalty to the protesters' cause, they also tended to injured soldiers and police officers and offered them critical medical relief, even when this incurred the wrath of protesters. Dr. Fattouh explained to us their ethical commitment by saying, "We acted as the change that we want to see in the world." 13

Physicians' narratives about the importance of their witnessing as the cause of their actions can best be read as a rhetorical practice that furthers their convictions rather than cause or initiate them. This reformulation of their own accounts repositions physicians as actors within society who are subject to the same social, economic, and political influences as are other members of society. Here again, our reformulation reveals that the argument that physicians form a special moral class is a problematic one, based not only on the dominant narrative of science as outside the social world of politics but also on the "doctor-as-savior-of-lives" narrative that comes from physicians' technical expertise. Their technical skills enable them to intervene in situations of critical injury or disease that can dramatically alter the course of bodily demise. Because of this expertise, physicians are granted special privileges that enable their access to patients' lives in moments of intense vulnerability. This enables them to see the aggregate of mass casualties in situations of political conflict, as did the Qasr El-Aini doctors when the most critical cases of Tahrir Square's wounded were referred to that single hospital center. The traumacenter doctors' privileges are both temporal and spatial: the doctor can access a patient's body in disease or injury during a window of time in which intervention can alter the course of life. Spatially, the trauma center concentrates the entire city's most critically injured. These spatial-temporal privileges of vantage point in the popular imagination across cultural and historical contexts are often conflated with the physicians' moral superiority.

In Redfield's account of MSF, he demonstrates how témoignage, the act of witnessing, in moments of crisis became a central and defining principle guiding the work of the transnational humanitarian group. He contrasts today's humanitarianphysician witness with that of Steven Shapin's and Simon Schaffer's seventeenth-

13 Interview with authors in June 2014. 
century English scientist- "witness"-the gentleman unrestrained by social dependencies and thus convincing as a party of "disinterest" and social reliability. Redfield argues that, in contrast, knowledge production in the contemporary world of MSF humanitarianism is explicitly politically interested, collective, and driven by a moral compulsion to act in opposition to the global production of suffering, inequality, and violence. Yet Redfield argues that there are still continuities in today's physician-humanitarian with the generative moral economy of early modern European science: here too, the witness emphasizes the moral significance of facts; facts identifiable through quantification, empiricism, and objectivity, relying on statistics, field laboratory studies and epidemiological data, which are reliable because of their self-claimed "independence" from political powers and even from the dictates of "neutrality and silence" (unlike the International Committee of the Red Cross, from which MSF grew, but also with which MSF contrasts itself). Like the seventeenth-century gentleman-scientists, the physician-humanitarians produce knowledge through what Redfield calls "the complex combination of self-restraint and self-effacement" (2006:17).

While the transnational and independent status of MSF often affords them some level of credibility in highly volatile political situations, in Egypt in the days leading to Mubarak's removal, any "foreign" or "transnational" organization was regarded with suspicion, and the early protestors fought against the official media narratives that they were spies or thugs paid off by foreign countries with the aim of destabilizing Egypt. The accounts of Egyptian physicians situated in well-known Egyptian hospitals were difficult to dismiss, as they had little incentive to work, for no pay, back-to-back shifts to stem the tide in the Emergency Department. Second, in the case of MSF, political and moral stances precede and inform the physicians' actions, whereas in the case of the Egyptian doctors, it was their actions as physicians - some who merely happened upon the scene, by virtue of their location in downtown medical centers-that formulated or crystallized their political positions. Third, and, for our purposes, most importantly, unlike the physicians of MSF, the Egyptian doctors did not see themselves as "without borders," i.e., deterritorialized, dispersed, or global in scale. It was their emplacement in Egypt as Egyptians that, aside from giving them credibility on the scene, also made their participation, in the name of medical neutrality, so threatening to a regime that claims for itself the sole authority to determine who can live and who can die.

\section{Political Contestation as a Condition of Medical Neutrality}

There is a paradox to physicians' identification with the concept of "medical neutrality" as a central tenet of their practice. In imagining their actions-treating the wounded and sick no matter who they are-as outside the realm of politics, they can, like in the story of Dr. Taha above, find themselves in unexpected situations. Dr. Taha, from his vantage point, did not initially agree with the protests that broke out in the alleys of Mohamed Mahmoud street in November 2011, having found compelling the line that the protesters needed to go home for the country to "get back on track." Yet because he understood medical neutrality to be his duty as a physician, he responded to the field hospital's plea for medical supplies. 
Dr. Taha felt that, regardless of his political views, his "sense of duty as a physician" impelled him to respond to the medical pleas. He went to the protests and witnessed a completely different scene than that depicted in the news. "There were bullet wounds, pellet wounds, and asthmatic people suffocating because of the gas," said Dr. Taha. "But what changed my standing [...]-and I will never forget this for as long as I live—on the rooftops, I saw, policemen and military aiming their guns-pellets or whatever - at the hospital. It wasn't incidental; they were aiming intentionally at the hospital, seeing people in white coats coming in and out... That was when I understood that what was happening was wrong; what the government was doing was terribly wrong and that in all cases [...] who shoots at hospitals?! The Red Cross people don't come under fire when they are in the middle of a battlefield; who does that?! So at that moment, I became a complete supporter of the protestors and the revolution."

Seeing the riot police's ruthless attacks on the unarmed protesters and, most importantly, on the field hospitals themselves made Dr. Taha realize that to practice medicine at all was to take a stand against the State's dehumanization of the protesters. When doctors argue that acting in the field hospitals during the uprisings was "only natural" given their profession and that "medical neutrality" is their professional ethos, they are justifying their having taken a political stance and simultaneously effacing that stance. This was the most common narrative that we heard among a younger group of physicians who, like the majority of people who occupied Tahrir Square, stated that they had no previous interest or knowledge of political events; they had never before participated or even thought deeply about their own political positions. There were also many physicians who initially joined the street demonstrations as protestors themselves, with their own grievances-whether about the unaffordable and precarious lives of young generations of highly educated medical professionals, the rights of poor patients, the dismal state of government spending on health, or their own rights to political freedom of expression. There were still other groups, such as the group Doctors Without Rights (founded in 2007), which makes an explicit argument that in order for doctors to fulfill their professional duties, the State must increase its expenditure on healthcare services, give physicians livable wages, and ensure the security of hospitals and the safety of the medical staff. As in the case of doctors thwarted by state violence at the field hospitals, those mobilizing around social and health rights have been stymied by a State that regards their claims as dangerous to its national security.

Ahmed Mahdi, one of the paramedics who volunteered at the makeshift hospitals in the early days of the protests, was a founding member of the organization Tahrir Doctors. Established in February 2011, the non-profit group was mostly comprised of young and middle-aged doctors and paramedics who found each other offering first aid in Tahrir Square. When we asked Ahmed about his role, he hesitated for a moment, and then said, "Honestly, whenever there are confrontations, I divide my time between being in the field hospital giving first aid to injured protesters, and being at the front line, hurling rocks myself with my fellow protesters at the police." Healthcare workers who took part in the demonstrations, either as protestors or as first-aid medics (and the separation 
between these two roles was not always stable or clear) were but one example of segments of Egyptian society entering, for the first time, into direct political dissent that risked disproportionate responses of state violence. In this, they are aligned with other Egyptians in the struggle: to demand medical neutrality was to demand from the State respect for human dignity, not to mark doctors as deserving of a special status or with special privileges.

In Didier Fassin's sympathetic critique of MSF, he points out how in humanitarians' commitment to the universality of human dignity and toward the suffering of fellow humans, humanitarianism is offered in opposition to divisive language (such as in racism or ethnic conflict) and in opposition to the indifference and apathy that marks suffering as something that occurs to "distant others" (Fassin 2007). Fassin then raises what he calls the "aporia" of humanitarianism, which is that in its act, it re-constitutes the very relationship of inequality that it seeks to address: when MSF, for example, debates whether it makes sense to risk the lives of its workers so that others can be saved, humanitarian agents are distinguished as lives that can be risked, while the subjects of humanitarianism are those that can only be sacrificed. Within the movement itself, expatriate humanitarian agents' lives are valued higher than those of nationals, as the case of abductions starkly reveals, and the lives of humanitarian agents can be narrated in the first person, while those who form the moral basis and medical knowledge of the reports are the "nameless" third-person voices in the name of which humanitarianism can be done.

Yet in the case of Egyptian doctors, their emplacement as Egyptian citizens within national borders means that their lives too, as those of the injured protestors, can be sacrificed. Indeed, physicians testifying at the December 2011 press conference held up their white medic coats on which they had written: "Martyrs On Demand." Their emplacement as Egyptian physicians made their willingness to tend to protestors all the more cogent a betrayal from the perspectives of the military soldiers.

Physicians were quick to join the protestors with their own political grievances-not as "protectors" of other citizens but as co-citizens who mobilized for their own rights. The group "Doctors Without Rights" organized the longest strike in Egypt's history following the political uprisings, and members of their group went on, after the removal of Mohamed Morsi from his short-lived presidency, to win the election within the Egyptian Medical Syndicate, breaking the National Democratic Party and Muslim Brotherhood's joint monopoly over the professional organization for the first time in over 19 years. Politics within the professional syndicates function as a sort of microcosm for some of the larger political struggles in Egypt, as well as in the broader Middle East region. In the case of the Medical Syndicate, stakes are particularly high, as the profession struggles not only for its own survival but also for the many more lives which it is committed to preserving. 


\section{Conclusion: The Stakes of Medical Neutrality: Local and Global}

Like the radical act of medical impartiality in which doctors attended to victims of state violence, the very act of witnessing and responding to this state violence was also an act involving great risk. Forensic pathologists and psychiatrists in particular stepped up, refusing to join the ranks of medical clinicians who succumbed to political pressures to deny the evidence of state violence. Yet there was nothing inherent or natural about their doing so. These physicians' actions, like those of the Egyptian protesters more generally, were the outcomes of decades of grievances against the State, as well as decades of political organization that allowed for a different form of governance to be imaginable and worth risking one's life for. Their actions were also informed by the global rhetoric linking international humanitarianism with the role of the medical worker.

The logic of medical neutrality rests on the notion that the physician's safety should be prioritized because it enables the safety of many other civilians, and, conversely, the dwindling of medical facilities and healthcare capacity endangers more lives. Yet from the perspective of a State willing to violate citizens' basic rights, a physician treating opponents is an opponent facilitating, enabling, condoning, justifying, and normalizing the opposition that it seeks to suppress. A physician appealing to medical impartiality is a disobedient citizen, hindering the consolidation of authority in times of crisis. Indeed, from the aggressor's point of view, if not wholly disciplined within the military regime, doctors are always a potential threat, because they can save lives and return protestors to the frontline.

As in the case of Dr. Taha, there were several such physicians who were expressly skeptical of the protestors, and others who claimed to have had no political leanings one way or the other, who, in the course of witnessing the unexpected and disproportionate use of state violence, became enraged and politicized against the State. This narrative upholds the assumption that the physician's role is confined to the clinic, and that only under extraordinary circumstances will it spill over into the world of politics. The notion that a physician is political only in times of exception seems to structure the notion that the Principle of Medical Neutrality exerts its own force: that physicians will be subject to political action only in exceptional cases of violence, where they should be met with immunity and protection. Given that medical neutrality was historically a convention among European nations since the nineteenth century based on the principle of reciprocity in protecting each other's wounded soldiers and refraining from targeting medical facilities, it should not be surprising that a State exhibiting brutal repression against its own citizens' dissent would not uphold such a norm. Moral and legal argumentation by humanitarian groups is unlikely to effect change; there are structural conditions that enable and help cultivate physicians' adherence to medical neutrality that need to be studied and implemented.

Yet even then, in condemning violations to medical neutrality only in times of political violence, we are eschewing the everyday violations that have become normalized in situations of structural violence. The deterioration of the country's 
medical services was one of the many powerful rallying calls of the popular uprisings that shook Egypt. One of the slogans chanted in Tahrir Square was: "Cancer is Everywhere, and the [Natural] Gas is Exported for Free." This slogan alluded to the State's mismanagement of toxic waste, corrupt deals with foreign oil companies, and lack of medical services. Another, alluding to the alarming participation of Egyptian physicians in profiteering in human body parts was: "They sold our blood, they sold our kidneys, and we beg, we and our families." (Abdel Hamid 2011) ${ }^{14}$ Poor disenfranchised patients have long suffered abuse from a corrupt and exploitative healthcare system; meanwhile, the deterioration of public infrastructure and the deregulation of toxic waste management of transnational corporate industry in Egypt have colluded to create alarming increases in incidences of cancers and organ failure throughout Egypt. In other words, the exceptionalism of the violations of medical neutrality, exhibited in the State's brutal attacks on field hospitals, healthcare workers, and injured protesters in times of political confrontation, risks overshadowing the "ordinariness" of structural violence perpetrated by a State against the health of its citizens and the dignity of its healthcare providers.

The ordinariness of human indignities is what led the protesters, and the doctors alongside them, to occupy the streets and to demand change and ultimately to sacrifice their lives through extraordinary acts of defiance. Medical neutrality, even when explicitly invoked by physicians on the frontlines, was never an accurate description of how they practiced, and certainly not descriptive of how the State responded to them. Even in writing about the State's violations of medical neutrality toward its own citizens, we elide the fact that the State had never recognized this norm to begin with. In invoking the notion of impartiality or neutrality, healthcare workers countered claims that subsume them as mere tools of power and attempted to model for wider society a belief in common humanity, a belief sorely needed in times of political and civil strife.

Acknowledgments We presented earlier versions of this paper at the CUNY Graduate Center's Workshop on "Delimiting Egypt: Nationality, Land, and Bodies," at Harvard's Science, Technology, and Society Circle, and at Brown University's "Clinic in Crisis" Symposium. We would like to thank all the participants and organizers for their helpful questions and comments. Sherine Hamdy's research was supported by the Greenwall Foundation Faculty Scholar Program in Bioethics and by a Watson Institute Collaborative Grant from Brown University. We would also like to thank two anonymous reviewers for their helpful feedback on an earlier version.

Funding This study was funded by the Greenwall Faculty Scholars Program in Bioethics and by a collaborative grant from the Watson Institute at Brown University.

\section{Compliance with Ethical Standards}

Conflict of interest Sherine Hamdy and Soha Bayoumi declare that they have no conflict of interest.

\footnotetext{
${ }^{14}$ For slogans, see http://angryarab.blogspot.com/2011/01/egyptian-slogans.html. Accessed 31 August 2014.
} 
Human and Animal Rights and Informed Consent All procedures performed in studies involving human participants were in accordance with the ethical standards of the institutional and/or national research committee and with the 1964 Helsinki declaration and its later amendments or comparable ethical standards. Informed consent was obtained from all individual participants included in this study.

\section{References}

Abdel Hamid, Mohamed Abdel Raouf

2011 Middle East Revolutions: An Environmental Perspective, http://www.mei.edu/content/middleeast-revolutions-environmental-perspective, accessed, March 16, 2015.

Amnesty International

2012 Acquittal of Egyptian Military Doctor Fails Women Victims of "Virginity Tests", http://www. amnesty.org/en/for-media/press-releases/acquittal-egyptian-military-doctor-fails-women-victimsvirginity-tests-2012, accessed August 31, 2014.

Birn, Anne-Emanuelle, and Theodore M. Brown

2013 Comrades in Health: U.S. Health Internationalists Abroad and at Home: Rutgers University Press, New Brunswick, NJ.

The Egyptian Initiative for Personal Rights

2011 Field Doctors Bear Witness to the Targeting of Field Hospitals in Tahrir Square by Security Forces and Military, http://eipr.org/node/1314, accessed February 27, 2015.

El-Fiki, Mohamed and Gail Rosseau

2011 The 2011 Egyptian Revolution: A Neurosurgical Perspective. World Neurosurgery 76(1/2).

Fahmy, Khaled

1997 All the Pasha's Men: Mehmed Ali, His Army, and the Making of Modern Egypt. Cambridge, UK: Cambridge University Press.

Fassin, Didier

2007 Humanitarianism as a Politics of Life. Public Culture 19(3): 499-520.

2012 Humanitarian Reason: A Moral History of the Present. Berkeley: University of California Press.

Gross, Michael

2006 Bioethics and Armed Conflict: Moral Dilemmas of Medicine and War. pp. 175-210. Cambridge, MA: MIT Press.

The Guardian.

2013 Egyptian doctors 'ordered to operate on protesters without anaesthetic', http://www.theguardian. com/world/2013/apr/11/egypt-doctors-.operate-protesters-anaesthetic, accessed February 26, 2015.

Gulland, Anne

2011 Volunteer Doctors are 'Better Organised' to Treat Casualties in Tahrir Square Than During Previous Unrest. BMJ. doi:10.1136/bmj.d7666.

Hamdy, Sherine

2012 Our Bodies Belong to God: Organ Transplants, Islam, and the Struggle for Human Dignity in Egypt. Berkley, CA: University of California Press.

Physicians for Human Rights. The Principle of Medical Neutrality. http://physiciansforhumanrights.org/

library/multimedia/principle-of-medical-neutrality.html, accessed February 26, 2015.

Redfield, Peter

2006 A Less Modest Witnesss. American Ethnologist 33(1): 3-26.

2011 The Impossible Problem of Neutrality. In Forces of Compassion: Humanitarianism Between Ethics and Politics. Peter Redfield and Erica Bornstein, eds. Santa Fe, NM: School for American Research Press.

2013 Life in Crisis: The Ethical Journey of Doctors Without Borders. Berkeley, CA: University of California Press.

Sarhan, MD, AA Dahaba, M Marco, and A Salah

2012 Mass Casualties in Tahrir Square at the Climax of the Egyptian Uprising. Annals of Surgery 256(6): 1093-1097.

Shukrallah, Alaa and Mohamed Hassan Khalil

2012 Egypt in Crisis: Politics, Health Care Reform and Social Mobilization for Health Rights. In Public 
Health in the Arab World, Eds. Samer Jabbour, Rita Giacaman and Marwan Khawaja, pp. 477-488. Cambridge; New York: Cambridge University Press.

World Medical Association. WMA Regulations in Times of Armed Conflict and Other Situations of Violence: http://www.wma.net/en/30publications/10policies/a20/, accessed February 26, 2015. 